\title{
PENGARUH KOMBINASI PEMBERIAN JUS JAMBU BIJI MERAH DAN MADU TERHADAP PENINGKATAN KADAR HB PADA IBU HAMIL
}

\author{
In Influence Of Combination Red Guava And Honey To Increase \\ Hb Level on Pregnant Women
}

\author{
Halimatus Saidah \\ Program Studi Kebidanan (DIV) Fakultas Ilmu Kesehatan Universitas Kadiri \\ Jl Selomangleng No. 1 Pojok Mojoroto Kota Kediri-Jawa Timur \\ Halimatus.saidah@unik-kediri.ac.id
}

\begin{abstract}
ABSTRAK
Anemia adalah kondisi dimana sel darah merah (eritrosit) menurun atau menurunnya hemoglobin, sehingga kapasitas daya angkut oksigen untuk kebutuhan organ pada ibu dan janin berkurang, Data dari Puskesmas Mrican pada bulan januari - maret tahun 2017 didapatkan jumlah ibu hamil di kelurahan Mrican dan Dermo yang mengalami anemia berjumlah 19 ibu hamil. Diantarannya di kelurahan mrican 12 ibu denganHB 7,6 - 8,8 gr/dl, dan di kelurahan Dermo 7 ibu dengan HB10,1 - 10,9 gr/dl..Tujuan penelitian ini adalah untuk mengetahui pengaruh pemberian kombinasi jus jambu biji merah dan madu terhadap peningkatan kadar hemoglobin pada ibu hamil.

Desain penelitian ini merupakan penelitian eksperimen dengan pendekatan One Group Pre TestPost Test Design dengan populasi 18 ibu hamil yang mengalami anemia, sampel diambil dengan menggunakan teknik Total Sampling. Variabel independent dalam penelitian ini adalah pemberian jus jambu biji merah dan madu sedangkan variable dependent adalah perubahan kadar HB pada ibu hamil dengan anemia. Pengumpulan data menggunakan data primer dengan menggunakan lembar observasi pengukuran Kadar HB sebelum dan sesudah pemeriksaan. Analisa penenelitian menggunakan uji t-test.

Hasil penelitian didapatkan Kadar $\mathrm{Hb}$ ibu sebelum mengkonsumsi kombinasi jus jambu biji merah dan madu didapatkan Mean 9,19 gr/dl, Median 9,30 gr/dl dan SD 9,87 gr/dl. Kadar Hb ibu sesudah mengkonsumsi kombinasi jus jambu biji merah dan madu didapatkan Mean 10,4 gr/dl, median 10,3 gr/dl, SD $5,19 \mathrm{gr} / \mathrm{dl}$. Hasil uji $t$-test dengan taraf signifikansi $\alpha=0,05$ didapatkan $p_{-}$value $=0,000$ ( $p_{-}$value $\left.<\alpha(0,05)\right)$ sehingga disimpulkan ada pengaruh pemberian kombinasi jus jambu biji merah dan madu terhadap peningkatan kadar $\mathrm{Hb}$ ibu hamil
\end{abstract}

Kata Kunci : Kombinasi Jus Jambu Biji Merah dan Madu, Anemia, Ibu Hamil

\begin{abstract}
Anemia is a condition in which red blood cells (erythrocytes) decreases or decreases in hemoglobin, so the oxygen transport capacity for the organs of the mother and fetus is reduced. Data from the Mrican Puskesmas in january-March 2017 found the number of pregnant women in the Mrican and Dermo villages experienced anemia of 19 pregnant women. In mrican village, 12 mothers with HB $7.6-8.8$ $\mathrm{gr} / \mathrm{dl}$, and in Dermo 7 mothers with HB 10,1 - 10,9 gr / dl. The purpose of this study was to determine the effect of combination of guava juice and honey on elevated levels of hemoglobin in pregnant women.

The design of this study is an experimental study with One group pre-test-post test design approach with population 18 pregnant women who have anemia and sampel get to total sampling. Variabel Independent is combination of red guava juice and honey and variabel dependent is increase pregnant women Hb level, the research is using t-test.

The result showed that mother's Hb level before consume combination of red guava juice and honey Mean 9,19 $\mathrm{gr} / \mathrm{dl}$, Median 9,30 gr/dl dan SD 9,87 gr/dl, mother's Hb content after consuming combination of guava juice of red and honey is Mean 10,4 gr/dl, median 10,3 gr/dl, SD 5,19 gr/d. Result of $t$ test with significance level $\alpha=0,05$ got $p_{-}$value $=0,000$ ( $p \_$value $<\alpha(0,05)$ ) so it concluded there is influence of combination of guava juice red and honey to increase pregnant women Hb level
\end{abstract}

Keywords: Combination of Red Guava Juice and Honey, Anemia, Pregnant Mother 


\section{PENDAHULUAN}

Kehamilan merupakan kondisi alamiah yang unik karena meskipun bukan penyakit, tetapi seringkali menyebabkan komplikasi akibat berbagai perubahan anatomik serta fisiologik dalam tubuh ibu.Salah satu perubahan yang terjadi pada masa kehamilan adalah perubahan system kardiovaskule ratau hemodinamik. Perubahan fisiologis alami yang terjadi selama kehamilan akan mengalami jumlah sel darah normal pada kehamilan.Peningkatan volumedarah ibu terjadi akibat peningkatan plasma,bukan akibat peningkatan jumlah sel darah merah. Walaupun ada peningkatan jumlah sel darah merah didalam sirkulasi, tetapi jumlahnya tidak seimbang dengan peningkatan volume plasma. Ketidakseimbangan ini akan terlihat dalam bentuk penurunan kadar hemoglobin yang pada akhirnya dapat menyebabkan anemia pada ibu hamil. (Prawirohardjo, 2009).

Pada ibu hamil terjadi beberapa komplikasi yang terjadi saat kehamilan salah satunya penyakit darah yaitu anemia dalam kehamilan, leokimia, purpura trombositopeni dan hipifbrinogenemia. Anemia sangat berbahaya bagi ibu yang sedang hamil. Penyakit anemia sering sekali menyerang pada masa kehamilan. Sebab pada saat hamil, kebutuhan ibu terhadap unsur unsur makanan semakin banyak, semisal zat besi, folic acid dan protein. Jika kebutuhan ini tidak mencukupi, ibu akan mengalami anemia sementara disisi lain ibu yang sedang hamil kadang lalai mengkonsumsi zat-zat ini khususnya zat besi dan folic acid yang pada umumnya ketidaktahuan ibu terhadap unsurunsur zat besi dalam makanan (Lamadhah, 2011).

Anemia secara praktis didefinisikan sebagai kadar hematokrit kosentrasi $\mathrm{Hb}$, atau hitungan eritrosit dibawah batas normal (Prawirohardjo,2009). Adapun faktor-faktor penyebab anemia antara lain kurang gizi( malnutrisi), kurang zat besi dalam diet, malabsorbsi, kehilangan darah yang banyak(persalinan yang lalu dan haid). Anemia dalam kehamilan memberi dampak kurang baik bagi ibu, baik dalam kehamilan, persalinan maupun nifas dan masa selanjutnya.Adapun dampak makro dan mikro yang dapat ditimbulkan akibat anemia oleh anemia. Dampak mikro yang dapat timbul akibat anemia adalah : keguguran (abortus), kelahiran prematur dan imatur, persalinan yang lama akibat kelelahan otot rahim di dalam berkontraksi ( inersia uteri), gangguan kontraksi uterus pasca persalinan (atonia uteri), syok, infeksi baik saat bersalin maupun pasca bersalin, serta dampak makro meliputi berat badan bayi lahir rendah, meningkatnya angka kematian perinatal serta anemia yang berat $(<4 \mathrm{gr} \%)$ dapat menyebabkan dekompensasi kordis. Hipoksia akibat anemia dapat menyebabkan syok dan kematian ibu pada persalinan ( Wiknjosastro, 2005; Saifudin, 2006).

Sampai saat ini tingginya angka kematian ibu di Indoneia masih merupakan prioritas di bidang kesehatan. Menurut WHO tahun 2011 di Indonesia terdapat 240/100.000 kelahiran hidup. Sedangkan AKI di Vietnam 56, Brunei 21, Malaysia 31, Thailand 48 dan Singapura hanya 9 per 100.000 kelahiran hidup (Depkes, 2011).

Di Provinsi Jawa Timur, Angka Kematian Ibu (AKI) pada tahun 2013 sebesar 104,3/100.000 kelahiran hidup. Pada tahun 2014 mengalami penurunan menjadi 97,43/100.000 kelahiran hidup yang salah satunya disebabkan oleh perdarahan $25,4 \%$, dan preeklampsi 2014.).

Dampak anemia dalam kehamilan dapat mempengaruhi kehamilan karena anemia dapat menurunkan daya tahan tubuh yang berakibat kematian janin dalam kandungan, abortus, cacat bawaan, berat badan lahir rendah (BBLR).Pada persalinan dapat menyebabkan inersia uteri, ibu menjadi lemas sehingga menimbulkan partus lama, sedangkan pada masa nifas dapat terjadi perdarahan dan pada keadaan ini tubuh tidak dapat mentoleransi seperti ibu yang sehat tidak menderita anemia. Hal ini menyebabkan morbiditas dan mortalitas serta kematian perinatal secara bermakna lebih tinggi (Manuaba, 2002).

Pencegahan pada ibu hamil dapat dilakukan dengan mencukupi kebutuhan zat besi. Selain itu dengan makanan seimbang perlu sekali untuk menjadi menu ibu hamil. Makanan yang kaya akan zat besi diantaranya adalah daging merah, sayuran berdaun hijau sereal dengan kandungan zat besi yang dibutuhkan tubuh, kacangkacangan dan telur. Selain itu dukung juga dengan vitamin $\mathrm{C}$ yang baik untuk mendapat 
menyerap lebih banyak zat besi, mengkonsumsi sari kurma, sayuran dan buah.

Pengobatan pada ibu hamil yang mengalami anemia dapat dengan mengkonsumsi tablet fe dan mengkonsumsi makanan seimbang yang mengandung zat besi, Asam folat, Vitamin $\mathrm{C}$ dan Vitamin B12 selain itu buah pisang ambon sangat baik karena zat besi yang cukup tinggi dapat merangsang produksi hemoglobin dalam darah bagi penderita anemia dan madu mengandung zat besi, vitamin $\mathrm{C}, \mathrm{A}$, dan $\mathrm{B} 12$ berfungsi pembentukan sel darah merah dan Hemoglobin ( Hidayah, 2011)

Berdasarkan penelitian yang dilakukan oleh Yeri Esti Ningtyastuti, Emy Suryani berkaitan dengan pengaruh konsumsi buah jambu biji merah terhadap kadar hemoglobin pada ibu hamil dengan anemia didapatkan hasil uji statistik $\rho$ value $(0,002) \alpha(0,05)$, yang berarti bahwa ada pengaruh mengkonsumsi buah jambu biji merah terhadap peningkatan kadar hemoglobin pada ibu hamil di Kelurahan Bandung Kecamatan Ngrampal Sragen.

Jambu biji merah mengandung vitamin C yang merupkan salah satu vitamin yang di perlukan oleh tubuh. Bila dalam tubuh kebutuhan vitamin dan mineral mencukupi, maka segala jenis penyakit dapat di cegah. Mengkonsumsi vitamin $\mathrm{C}$ yang juga berfungsi sebagai antioksidan terbukti dapat menagkal virus-virus, sehingga bila cukup memenuhi kebutuhan ini, maka akan lebih jarang mengalami flu (Adhyzal,2008). Kandungan zat besi yang cukup tinggi dalam jambu biji merah dapat merangsang produksi hemoglobin dalam darah bagi penderita anemia ( Hidayah, 2011). Bagi penderita anemia disarankan untuk mengkonsumsi buah jambu biji merah secara rutin, hal ini sangat baik untuk meningkatkan kadar hemoglobin ( Prawirohardjo, 2009).

Hasil penelitian Wulandari Tahun 2015, bahwa madu mengandung Vitamin C, Vitamin A, besi ( $\mathrm{Fe}$ ), dan Vitamin B12 yang berfungsi sebagai pembentuk sel darah merah dan Hemoglobin. Sehingga dapat disimpulkan bahwa mengkonsumsi madu dapat mencegah anemia defisiensi besi pada ibu hamil. Madu merupakan cairan gula supernatan. Madu memiliki kandungan zat gula berupa fruktosa dan glukosa yang merupakan jenis gula monosakarida yang dapat diserap oleh usus. Selain itu, madu mengandung vitamin, mineral, asam amino, dan bahan-bahan aromatik. 17,1\% air, 82,4\% karbohidrat total $0,5 \%$ protein,hormon antibiotik asam amino, vitamin dan mineral. Selain itu asam amino nonesensial ada juga asam amino esensial diantaranya lysin, histadin, dan triftofan

Data dari Puskesmas Mrican pada bulan januari - maret tahun 2017 didapatkan jumlah ibu hamil di kelurahan Mrican dan Dermo yang mengalami anemia berjumlah 19 ibu hamil. Diantarannya di kelurahan mrican 12 ibu denganHB 7,6 - 8,8 gr/dl, dan di kelurahan Dermo 7 ibu dengan HB10,1 $10,9 \mathrm{gr} / \mathrm{dl}$. Hal Ini di karenakan kurangnya pengetahuan ibu tentang pentingnya mengkonsumsi makanan bergizi. Selain itu belum mengetahui bahwa pada buah jambu biji merah sangat baik untuk meningkatkan kadar hemoglobin.

Berdasarkan data tersebut, peneliti tertarik untuk melakukan penelitian tentang pengaruh pemberian jus jambu biji merah dan madu terhadap peningkatan kadar hemoglobin pada ibu hamil dengan anemia di Kelurahan Mrican dan Dermo Wilayah Kerja Puskesmas Mrican Tahun 2017.

\section{METODE PENELITIAN}

Rancangan yang digunakan berdasarkan lingkup penelitian termasuk jenis penelitian inferensial. Berdasarkan tujuan penelitian termasuk penelitian eksperimen. Berdasarkan tempat penelitian termasuk jenis penelitian lapangan, berdasarkan waktu pengumpulan data termasuk jenis penelitian longitudinal, berdasarkan cara pengumpulan data termasuk jenis penelitian observasional. Kelompok subjek di observasi sebelum dilakukan perlakuan, kemudian di observasi lagi setelah perlakuan. Berdasarkan ada tidaknya perlakuan termasuk dalam penelitian Preeksperimen dengan pendekatan one Group Pre-test and Post-test Design. Di dalam desain penelitian ini observasi dilakuan sebanyak 2 kali yaitu sebelum dan sesudah perlakuan, berdasarkan sumber data termasuk jenis data primer.

Populasi dalam penelitian ini adalah 18 orang ibu hamil yang mengalami anemia di kelurahan mrican dan dermodi wilayah kerja Puskesmas Mrican pada bulan juli tahun 2017 dengan sampel semua populasi dijadikan sebagai sampel penelitian yaitu 
berjumlah 18 orang ibu hamil. Variabel bebas (Indenpendent) adalah pemberian jus jambu biji merah dan madu dan variabel terikat (Dependent) adalah perubahan kadar hemoglobin pada ibu hamil dengan anemia.

Instrumen penelitian yang digunakan dalam penelitian ini adalah alat ukur digital untuk memeriksa atau mengukur kadar Hemoglobin pada ibu hamil dan mengetahui ibu hamil yang mengalami anemia. Selain itu, menggunakan lembar observasi untuk mencatat hasil pemeriksaan hemoglobin sebelum dan sesudah mengkonsumsi jus jambu biji merah dan madu.

Dalam penelitian ini dilakukan uji normalitas terlebih dahulu untuk mengetahui data berdistribusi normal atau tidak menggunakan metode analitis parameter Shapiro Willk. Distribusi data dikatakan normal apabila $\mathrm{p}>0,05$. Skala yang digunakan adalah skala rasio dan sampel berpasangan dengan jumlah pasangan. Jika data berdistribusi normal menggunakan uji t sampel berpasangan, jika data berdistribusi tidak normal menggunakan uji peringkat bertanda Wilcoxon.

\section{HASIL DAN PEMBAHASAN}

\section{A. Data Umum}

\section{Karakteristik Responden Berdasarkan Usia}

Tabel 1. Distribusi Frekuensi Karakteristik Responden Berdasarkan Usia

\begin{tabular}{ccc}
\hline Usi Responde & Frekuensi & $\begin{array}{c}\text { Presentase } \\
(\%)\end{array}$ \\
\hline$<20$ tahun & 0 & 0 \\
20-35 tahun & 12 & 66,7 \\
$>35$ tahun & 6 & 33,3 \\
\hline Jumlah & 18 & 100,0 \\
\hline
\end{tabular}

Berdasarkan tabel 1 dapat diinterprestasikan bahwa sebagian besar yaitu 12 responden $(66,7 \%)$ ibu hamil dengan anemia di kelurahan mrican dan dermo berumur 20-35 tahun

\section{Karakteristik Responden Berdasarkan} Pendidikan

Tabel 2. Distribusi Frekuensi Karakteristik Responden Berdasarkan Pendidikan

\begin{tabular}{lcc}
\hline Pendididkan & Frekuensi & Presentase \\
\hline Dasar & 3 & 16,7 \\
Menengah & 5 & 28,7 \\
Tinggi & 10 & 55,6 \\
\hline \multicolumn{1}{c}{ Jumlah } & 18 & 100,0 \\
\hline
\end{tabular}

Berdasarkan tabel 2 dapat diinterprestasikan bahwa hampir sebagian yaitu 10 responden $(55,6 \%)$ pendidikan ibu hamil di kelurahan mrican dan dermo adalah pendidikan tinggi

\section{Karakteristik Responden Berdasarkan Pekerjaan}

Tabel 3. Distribusi Frekuensi Karakteristik Responden Berdasarkan Pekerjaan

\begin{tabular}{|c|c|c|}
\hline Pekerjaan & Frekuensi & $\begin{array}{c}\text { Presentase } \\
(\%)\end{array}$ \\
\hline IRT & 16 & 88,9 \\
\hline Swasta & 0 & 0 \\
\hline Wiraswasta & 2 & 11,1 \\
\hline PNS & 0 & 0 \\
\hline Jumlah & 18 & 100,0 \\
\hline
\end{tabular}
diinterprestasikan bahwa hampir seluruh yaitu 16 responden $(88,9 \%)$ ibu hamil di kelurahan mrican dan dermo mempunyai pekerjaan IRT. 
B. Data Khusus

1. Kadar HB (Hemoglobin) Ibu Hamil dengan Anemia Sebelum Pemberian Jus Jambu Biji Merah dan Madu

Tabel 4 Distribusi Frekuensi Kadar Hemoglobin Sebelum Pemberian Jus Jambu Biji Merah dan Madu Pada Ibu Hamil dengan Anemia

\begin{tabular}{llllllll}
\hline Variabel & N & Mean & Median & Mode & SD & Min & Max \\
\hline Kadar Hb & 18 & 9,19 & 9,30 & 9,30 & 9,87 & 7 & 10 \\
Sebelum Pemberian & & & & & & & \\
Jus Jambu Biji & & & & & & & \\
Merah dan Madu & & & & & & & \\
\hline
\end{tabular}

Berdasarkan tabel 4 dapat diinterprestasikan bahwa kadar hemoglobin sebelum pemberian jus jambu biji merah dan madu memiliki mean 9,19 gr/dl, median 9,30 gr/dl, modus 9,30 gr/dl dan standar deviasi 9,87.

\section{Kadar HB (Hemoglobin) Ibu Hamil dengan Anemia Sesudah Pemberian Jus Jambu Biji Merah dan Madu}

Tabel 5. Distribusi Frekuensi Kadar Hemoglobin Sesudah Pemberian Jus Jambu Biji Merah dan Madu Pada Ibu Hamil dengan Anemia

\begin{tabular}{lcllcccc}
\hline Variabel & N & Mean & Median & Mode & SD & Min & Max \\
\hline Kadar Hb & 18 & 10,4 & 10,3 & 10,2 & 5,19 & 9 & 11 \\
Sebelum Pemberian & & & & & & & \\
Jus Jambu Biji & & & & & & & \\
Merah dan Madu & & & & & & & \\
Berdasan & & & &
\end{tabular}

Berdasarkan tabel 5 dapat diinterprestasikan bahwa kadar hemoglobin sesudah pemberian jus jambu biji merah dan madu memiliki mean 10,4 gr/dl, median 10,3 gr/dl, modus 10,2 gr/dl dan standar deviasi 5,19.

\section{Analisis Uji Kadar Hemoglobin Normalitas sebelum dan sesudah Pemberian Jus Jambu Biji Merah dan Madu pada Ibu Hamil Dengan Anemia}

Tabel 6 Uji Normalitas Kadar Hemoglobin sebelum dan sesudah pemberian Jus Jambu Biji Merah dan Madu pada Ibu Hamil dengan Anemia

Tests of Normality

\begin{tabular}{|l|r|r|r|r|r|r|}
\hline & \multicolumn{3}{|c|}{ Kolmogorov-Smirnov $^{a}$} & \multicolumn{3}{c|}{ Shapiro-Wilk } \\
\cline { 2 - 8 } & Statistic & $d f$ & \multicolumn{1}{|c|}{ Sig. } & Statistic & Df & \multicolumn{1}{c|}{ Sig. } \\
\hline Hb_Sebelum &, 184 & 18 &, 109 &, 926 & 18 &, 162 \\
Hb_Sesudah &, 128 & 18 &, $200^{*}$ &, 906 & 18 &, 074 \\
\hline
\end{tabular}

Pada uji normalitas menggunakan Shapiro Wilk kadar hemoglobin sebelum mengkonsumsi jus jambu biji merah dan madu nilai $p_{\text {_value }}>$ nilai signifikan $(0,162>0,05)$, hal ini berarti data berdistribusi normal, sedangkan kadar hemoglobin sesudah mengkonsumsi jus jambu biji merah dan madu nilai $p \_v a l u e>$ nilai signifikan $(0,162>0,05)$, hal ini berarti data berdistribusi normal.

Maka uji normalitas sebaran data dapat di simpulkan $p_{-}$value > $a$ dengan $a=0,005$, Sehingga sebaran data normal dan dapat digunakan uji parametrik dengan uji $t$ sampel berpasangan. 


\section{Perbedaan Kadar Hemoglobin Sebelum dan Sesudah Pemberian Jus Jambu Biji Merah dan Madu pada Ibu Hamil dengan Anemia di Kelurahan Mrican dan Dermo Tahun 2017}

Tabel 7 Perbedaan Kadar Hemoglobin sebelum dan sesudah pemberian Jus Jambu Biji Merah dan Madu pada Ibu Hamil dengan Anemia

\begin{tabular}{lccc}
\hline Variabel & Mean & SD & SE \\
\hline Kadar hemoglobin sebelum perlakuan & 9,19 & 987 & 232 \\
Kadar hemoglobin sesudah perlakuan & 10,4 & 519 & 122 \\
Selisih kadar hemoglobin sebelum dan sesudah & 1,21 & 468 & 110 \\
Perlakuan & & &
\end{tabular}

$P_{-}$value $=0,000 \quad a=0,05$

Pada tabel 7 dapat diinterpretasikan bahwa kadar hemoglobin sebelum pemberian jus jambu biji merah da madu sebesar 9,19 gr/dl dan sesudah pemberian jus jambu biji merah dan madu sebesar $10,4 \mathrm{gr} / \mathrm{dl}$ sehingga dapat dilihat adanya perbedaan sebesar $1,21 \mathrm{gr} / \mathrm{dl}$ kadar hemoglobin sebelum dan sesudah pemberian jus jambu biji merah dan madu.

Hasil uji t sampel berpasangan menunjukan angka signifikan sebesar 0,000 yang artinya kurang dari $a=0,05$ dengan demikian $\mathrm{H} 0$ di tolak berarti ada pengaruh pemberian jus jambu biji merah dan madu terhadap peningkatan kadar hemoglobin pada ibu hamil dengan anemia di kelurahan mrican dan dermo tahun 2017.

Berdasarkan hasil analisis pada tabel di atas sebelum pemberian jus jus jambu biji merah dan madu kadar hemoglobin ibu hamil dengan anemia di kelurahan mrican dan dermo yaitu 9,19 gr/dl kadar hemoglobinnya 9-10 gr \% atau termasuk anemia ringan. Anemia adalah penurunan kualitas sel darah merah dalam sirkulasi, abnormalitas kandungan hemoglobin, sel darah merah atau keduanya. Anemia akibat gangguan pembentukan sel darah merah terjadi jika jumlah besi tidak adekuat atau kekurangan asamfolat, vitamin $\mathrm{B}_{12}$ atau globulin. Anemia berarti defisiensi sel darah merah yang dapat disebabkan karena kehilangan sel darah merah yang terlalu banyak atau pembentukan sel darah merah yang terlalu lambat (Ganong, 2008). Dikatakan tidak anemia $\mathrm{Hb}>11$ gr \%, anemia ringan $\mathrm{Hb}$ 9-10 gr \%, anemia sedang $\mathrm{Hb} 7-8$ gr \% dan anemia berat jika kadar $\mathrm{Hb}$ $<7$ gr\% 7-8 gr \% (Setiawan 2012).

Banyaknya ibu hamil yang memiliki kadar hemoglobin $\mathrm{Hb} \quad 9-10 \quad \mathrm{gr} \%$ atau mengalami anemia ringan di kelurahan mrican dan dermo di sebabkan oleh kurangnya asuhan gizi dalam tubuh. Zat besi di butuhkan untuk produksi hemoglobin. Sumber zat besi terdapat dimakanan bersumber dari hewani dimana hati merupakan merupakan sumber yang paling banyak mengandung $\mathrm{Fe}$ ( antara $6.0 \mathrm{mg}$ sampai14,0 mg). Sumber lain juga berasal dari tumbuh-tumbuhan tetapi kecil kandungannya sehingga bisa diabaikan. Zat besi dalam makanan berbentuk hem yaitu berikatan dengan protein atau dalam bentuk nonhem yang berbentuk senyawa besi inorganik yang kompleks. Zat besi hem lebih banyak diabsorbsi dibanding zat besi nonhem. Sumber zat besi hem adalah hati, ginjal, daging, ayam, ikan dimana dalam usus diserap $15.35 \%$. Sumber nohem umumnya terdapat dalam makanan yang berasal dari tumbuh-tumbuhan seperti sayur- sayuran, biji-bijian, kacang-kacangan, buah-buahan, dan serelia, sedikit dalam daging, ikan, dan telur ( Gibson 2009). Dari hasil penelitian yang di lakukan di kelurahan mrican dan dermo hampir seluruh yaitu 16 orang $(88,9$ $\%)$ responden mempunyai pekerjaan yaitu sebagai ibu rumah tangga. Beberapa pengamatan menunjukan bahwa anemia yang di derita oleh masyarakat terjadi karena kekurangan gizi hal ini di sebabkan oleh karena tingkat sosial ekonomi yang rendah (Manuaba, 2010).

Berdasarkan hasil analisis pada tabel diatas sesudah pemberian jus jambu biji merah dan madu di kelurahan mrican dan dermo yaitu 10,4 gr /dl kadar hemoglobinnya 9-10 gr \% mengalami anemia ringan. Menurut Winkanda ( 2013 ), Jambu biji 
merah merupakan salah satu jenis buah yang baik untuk memenuhi kebutuhan akan vitamin baik pada anak-anak maupun orang dewasa dan ibu hamil. Jambu biji merah mengandung vitamin $\mathrm{C}$ yang di anggap sebagai antioksidan untuk menambah daya tahan tubuh. Studi ilmiah menunjukan bahwa konsumsi rutin buah-buahan yang kaya vitamin $\mathrm{C}$ akan membantu tubuh meningkatkan kekebalan terhadap agen infeksi dan mengurangi dampak radikal bebas berbahaya penyebabab kanker dari tubuh. Selanjutnya vitamin $\mathrm{C}$ di perlukan untuk pembentukan kolagen dalam tubuh. Kolagen adalah protein struktural utama dalam tubuh manusia yang di perlukan untuk menjaga integritas pembuluh darah, kulit, organ, dan tulang. Madu adalah bahan makanan yang berpotensi sebagai basa.Unsur unsur yang bersifat basa adalah kalium, natrium, kalsium, magnesium. Manfaat madu yang sedemikian besar yaitu mampu membasakan suasana lambung dan kandungan monosakarida yang sangat mudah dan cepat diserap oleh tubuh. Maka jika madu dikonsumsi oleh ibu hamil yang mengalami anemia hal tersebut akan meringankan keluhan selama kehamilan karena peningkatan hormon yang menurunkan mortilitas traktus digestivus, sehingga pengosongan lambung yang lama turut merangsang peningkatan sekresi $\mathrm{HCl}$,rangsangan mual dapat diantisipasi jika tubuh dapat mengkompesasi metabolisme glikogen di hati yang terjadi saat pagi hari dengan konsumsi madu sebelum bangkit dari tempat tidur (Sa'id Hamad, 2007 : 134).

Banyaknya responden yang memiliki $\mathrm{Hb}$ 9-10 gr \% mengalami anemia ringan di sebabkan oleh faktor kurangnya mengkonsumsi jambu biji merah dan madu. Kandungan protein pada jambu biji merah dan madu memiliki banyak manfaat untuk kesehatan tubuh. Beberapa manfaat antara lain : menjaga sistem kekebalan tubuh, mencegah penyakit diabetes gestational, membantu mengatasi kekurangan zat besi, mencegah penyakit anemia pada ibu hamil, menurunkan kolestrol, dan mencegah gangguan pencernaan pada ibu hamil. (Buckle et al 2010). Oleh sebab itu dengan mengkonsumsi jus jambu biji merah dan madu kadar hemoglobin akan meningkat dan tingkat anemia menurun.
Hasil uji $t$ sampel berpasangan didapatkan bahwa nilai $p_{\text {_value }}$ (sing) 0,000 $<a(0,05)$ dengan demikian maka $\mathrm{H}_{0}$ ditolak dan $\mathrm{H}_{1}$ diterima maka ada pengaruh pemberian jus jambu biji merah dan madu terhadap peningkatan kadar Hemoglobin pada ibu hamil dengan anemia. Kadar $\mathrm{Hb}$ minimum sebelum pemberian jus jambu biji merah dan madu 7 sedangkan kadar $\mathrm{Hb}$ minimum sesudah pemberian jus jambu biji merah dan madu yaitu 9. Hal tersebut menandakan bahwa jus jambu merah dan madu dapat meningkatkan kadar hemoglobin pada ibu hamil dengan anemia.

Jambu biji merah mengandung vitamin $C$ yang di anggap sebagai antioksidan untuk menambah daya tahan tubuh. Studi ilmiah menunjukan bahwa konsumsi rutin buahbuahan yang kaya vitamin $\mathrm{C}$ akan membantu tubuh meningkatkan kekebalan terhadap agen infeksi dan mengurangi dampak radikal bebas berbahaya penyebabab kanker dari tubuh. Selanjutnya vitamin $\mathrm{C}$ di perlukan untuk pembentukan kolagen dalam tubuh. Kolagen adalah protein struktural utama dalam tubuh manusia yang di perlukan untuk menjaga integritas pembuluh darah, kulit, organ, dan tulang. Madu adalah bahan makanan yang berpotensi sebagai basa.Unsur unsur yang bersifat basa adalah kalium, natrium, kalsium, magnesium. Manfaat madu yang sedemikian besar yaitu mampu membasakan suasana lambung dan kandungan monosakarida yang sangat mudah dan cepat diserap oleh tubuh. Maka jika madu dikonsumsi oleh ibu hamil yang mengalami anemia hal tersebut akan meringankan keluhan selama kehamilan karena peningkatan hormon yang menurunkan mortilitas traktus digestivus, sehingga pengosongan lambung yang lama turut merangsang peningkatan sekresi $\mathrm{HCl}$,rangsangan mual dapat diantisipasi jika tubuh dapat mengkompesasi metabolisme glikogen di hati yang terjadi saat pagi hari dengan konsumsi madu sebelum bangkit dari tempat tidur (Sa'id Hamad, 2007 : 134).

Dari hasil penelitian di kelurahan mrican dan dermo menunjukan bahwa kadar hemoglobin responden sebelum pemberian jus jambu biji merah dan madu yaitu 9,19 gr/dl kadar hemoglobinnya sebesar 9-10 gr/dl, sesudah pemberian jus jambu biji merah dan madu yaitu 10,4 gr/dl kadar 
hemoglobinnya 9-10 gr/dl atau kadar hemoglobin responden sesudah pemberian jus jambu biji merah dan madu mengalami peningkatan. memang memiliki pengaruh signifikan dalam meningkatkan kadar $\mathrm{Hb}$ pada ibu hamil di kelurahan mrican dan dermo Tahun 2017. Jambu biji merah mengandung vitamin $\mathrm{C}$ yang di anggap sebagai antioksidan untuk menambah daya tahan tubuh. Studi ilmiah menunjukan bahwa konsumsi rutin buah-buahan yang kaya vitamin $\mathrm{C}$ akan membantu tubuh meningkatkan kekebalan terhadap agen infeksi dan mengurangi dampak radikal bebas berbahaya penyebabab kanker dari tubuh. Selanjutnya vitamin $\mathrm{C}$ di perlukan untuk pembentukan kolagen dalam tubuh. Kolagen adalah protein struktural utama dalam tubuh manusia yang di perlukan untuk menjaga integritas pembuluh darah, kulit, organ, dan tulang.

Berdasarkan data yang diperoleh dan teori menunjukan bahwa terdapat pengaruh signifikan pemberian jus jambu biji merah dan madu terhadap peningkatan kadar hemoglobin pada ibu hamil dengan anemia.

\section{KESIMPULAN DAN SARAN}

Berdasarkan hasil penelitian yang dilakukan dikelurahan mrican dan dermo Tahun 2017 dapat disimpulkan:

1. Kadar $\mathrm{Hb}$ ibu sebelum mengkonsumsi jus jambu biji merah dan madu di kelurahan mrican dan dermo tahun 2017 rata -rata 9,19 gr/dl kadar hemoglobinnya sebesar 9-10 gr/dl atau mengalami anemia ringan.

2. Kadar $\mathrm{Hb}$ ibu sesudah mengkonsumsi jus jambu biji merah dan madu di kelurahan mrican dan dermo tahun 2017 sebagian besar yaitu 10,4 kadar hemoglobinnya sebesar 9-10 gr/dl atau mengalami anemia ringan.

3. Ada pengaruh pemberian jus jambu biji merah dan madu terhadap peningkatan kadar $\mathrm{Hb}$ ibu hamil sebelum dan sesudah mengkonsumsi jus jambu biji merah dan madu pada ibu hamil dengan anemia di kelurahan mrican dan dermoKota Kediri Tahun 2017.

Penelitian ini dapat menjadi masukan bagi tenaga kesehatan untuk meningkatkan kadar $\mathrm{Hb}$ pada ibu hamil yang mengalami anemia dengan cara yang mudah dan murah guna mencegah terjadinya perdarahan saat persalinan berlangsung.

\section{DAFTAR PUSTAKA}

Arisman, (2012). Anemia Dan Anemia Dalam Kehamilan. Yogyakarta : Nuha Medika

Bakta, (2011). Buku Pola Konsumsi dan Kadar Hemoglobin Pada Ibu Hamil di Kabupaten Maros Sulawesi Selatan. Makara Kesehatan , 31-36.

Damia, (2012). Meningkatkan Hemoglobin Darah. Jakarta: PT Gramedia Pustaka Utama.

Depkes RI (2012) Profil Kesehatan Indonesia 2014. Jakarta: Departemen Kesehatan RI

Dinkes Provinsi Jawa Timur (2014). Profil Kesehatan Provinsi Jawa Timur tahun 2013. Surabaya: Dinkes Provinsi Jawa Timur.

Dinkes Kota Kediri, (2015). Profil Dinas Kesehatan Kota Kediri. Kota Kediri

Dewi, ( 2011). Ilmu Kebidanan. Jakarta: PT Bina Pustaka

Fatimah, (2011). Metode Penelitian. Jakarta : Ghalia Indonesia

Erwin, ( 2011). Dasar-dasar Keperawatan Kesehatan Masyarakat. Jakarta : EGC

Gibson, (2014). Faktor yang Berhubungan dengan Anemia Gizi pada Ibu Hamil di Puskesmas Jalaksana Kuningan Tahun 2010. Jurnal Kesehatan Kartika. Kuningan

Kementerian Kesehatan RI. (2015) Profil Kesehatan Indonesia Tahun 2014. Jakarta : Kementerian Kesehatan RI. 2015

Manuaba, (2011). Asuhan Kehamilan untuk kebidanan. Jakarta : Salemba Medika

Manuaba, I. B. (2011). Ilmu Kebidanan, Penyakit Kandungan \& Keluarga Berencana untuk Pendidikan Bidan. Jakarta: EGC.

Notoatmodjo, (2012). Metodologi Penelitian Kesehatan. Edisi revisi. Jakarta : Rineka Cipta 
Nurmayanti R, (2014). Efektifitas Konsumsi Telur Ras Terhadap peningkatan Kadar Hb Pada Ibu Hamil Trimester II. Skripsi. Poltekkes Kemenkes Surakarta : Prodi D IV Kebidanan

Nursalam. (2003). Konsep dan Penerapan Metodologi Penelitian Ilmu Keperawatan. Jakarta : Salemba Medika

Prawirohardjo, S. (2011). Ilmu Kebidanan. Jakarta: PT Bina Pustaka

Romauli, (2011). Asuhan kehamilan Kebidanan.Yogyakarta : PUSTAKA BARU PRESS

Romauli. Suryati.(2011). Asuhan Kebidanan 1 Konsep Dasar Asuhan Kebidanan. Yogyakarta: Nuha Medika.

Saifuddin, A. B. dkk. (2011). Buku Panduan Praktis Pelayanan Kesehatan

Maternal dan Neonatal. Jakarta: Yayasan Bina Pustaka

Sugiono, (2012) Metode Penelitian. Jakarta : Ghalia Indonesia

Sulistyawati, A. (2014). Asuhan Kebidanan pada Masa Kehamilan. Jakarta : JNPK-KR

Supratina ( 2011).Lengkap Menu Sehat Hamil. Yogyakarta: Garailmu

Siwi, Wylle. 2015. Konsep Manajemen Kebidanan. Jakarta: Salemba Medika

Taufan Nugroho,(2014). Asuhan kehamilan Kebidanan. Jakarta: EGC

Ummi Hani, (2011). Asuhan Kehamilan untuk kebidanan. Yogyakarta : Nuha Medika

Vivian dan Tri Sunarsih, (2011). Ilmu Kebidanan pada kehamilan fisiologis. Jakarta: EGC

Walyani, (2015). Asuhan Kebidanan I. Jakarta: Trans Info Media.

Wikipedia, (2011). Lengkap Menu Sehat Hamil. Yogyakarta: Garailmu. 